\title{
International Journal of Economics and Finance
}

www.ccsenet.org/journal.html

\section{An Overview Study on Dornbusch Overshooting Hypothesis}

\author{
Wenwen Tu \\ Department of Economics \\ School of Business, Nanjing University \\ Nanjing 210093, China \\ E-mail: winnie1225_tu@hotmail.com \\ Junwen Feng \\ School of Economics and Management \\ Nanjing University of Science and Technology \\ Nanjing 210094, China \\ E-mail: Fengjunwen8@hotmail.com
}

\begin{abstract}
Thirty years have passed since Dornbusch first published his overshooting hypothesis on "Expectations and Exchange Rate Dynamics". Reviewing and appraising the advantages and disadvantages of this elegant model in international economics is of great importance to the consideration of establishing exchange rate and macro-economic policy in the future. In this paper, the author provides an analysis and empirical evidence for and against this influential model. Some conclusions are drawn from an all-sided discussion.
\end{abstract}

Keywords: Dornbusch overshooting hypothesis, Exchange rate, Macro-economic policy

\section{Outline of Dornbusch Overshooting Hypothesis (DOH)}

The Dornbusch overshooting hypothesis (DOH) was first written as "Expectations and Exchange Rate Dynamics" by economist Rudiger Dornbusch and was published in the Journal of Political Economy in 1976. Everyone calls this masterpiece marks the birth of modern international macroeconomics (Rogoff, 2002).

The hypothesis develops a simple macroeconomic framework for the study of exchange rate movements. The purpose is to develop a theory that is suggestive of the observed large fluctuations in exchange rates while at the same time establishing that such exchange rate movements are consistent with rational expectations formation (Dornbusch, 1976).

The model assumes a country that is small in the world capital market so that it faces a given interest rate. Perfect capital mobility will ensure the equalization of expected net yields so that the domestic interest rate, less the expected rate of depreciation, will equal the world rate. In the goods market we will assume that the world price of imports is given. Domestic output is an imperfect substitute of imports, and aggregate demand for domestic goods, therefore, will determine their absolute and relative price (Dornbusch, 1976). Both the goods market and money market are in equilibrium. Purchasing Power Parity (PPP) holds in the long-run. Moreover, while commodity prices are sticky (slow to adjust), assets prices (i.e. exchange rate) adjust instantaneously in response to new information.

Three relationships lie at the heart of the overshooting result. The equation (1) below, where $r$ is the domestic interest rate, $\mathrm{r}^{*}$ is the given world rate of interest and $\mathrm{x}$ is the expected rate of depreciation of the domestic currency, is a representation of perfect capital mobility:

$$
\mathrm{r}=\mathrm{r}^{*}+\mathrm{x}=\mathrm{r}^{*}+\theta\left(\mathrm{e}^{\prime}-\mathrm{e}\right)
$$

This also states that the expected rate of depreciation of the spot rate in proportional to the discrepancy between the long-run rate and the current spot rate, where $\theta$ is the coefficient of adjustment, e' and e are the long-run rate and the short-run rate respectively.

The second core equation is the condition of equilibrium in the domestic money market. The demand for real money balances is assumed to depend on the domestic interest rate and real income, which equals the real money supply (Dornbusch, 1976). Assuming a conventional demand for money, the log of which is linear in the log of real income and in interest rates, we have: 


$$
\mathrm{m}-\mathrm{p}=-\alpha \mathrm{r}+\varphi \mathrm{y}
$$

Where $\mathrm{m}, \mathrm{p}$, and y denote the logs of the nominal quantity of money, the price level and real income; both $\alpha$ and $\varphi$ are positive parameters and they are interest elasticity of demand for money and income elasticity of supply for money respectively.

The third equation is the demand function for domestic output which depends on the relative price of domestic goods, e $-p$, interest rates and real income (Dornbusch, 1976). It is derived from aggregate demand function and is assumed to have the form

$$
\ln \mathrm{D}=\mathrm{u}+\mathrm{Yy}+\mathrm{a}(\mathrm{e}-\mathrm{p})-\mathrm{br}
$$

Where $\mathrm{D}$ denotes the demand of domestic output and $\mathrm{u}$ is a shift parameter.

Now, an increase in the supply for money that is expected to persist will cause a goods and asset market disequilibrium at the initial exchange rate and price (Figure 1). The $45^{\circ}$ line $\mathrm{R}$ is drawn through the origin on the assumption that PPP holds in the long-run. The QQ schedule reflects that money market equilibrium and international arbitrage of net expected yields. The positively sloped schedule $\mathrm{P} .=0$ shows combinations in price levels and exchange rates for which the goods market and money market are in equilibrium. The economy in initial full equilibrium at point A, with a long-run price level $\mathrm{P}^{\circ}$ and a corresponding long-run exchange rate $\mathrm{e}^{\circ}$ where the level of prices is determined.

Insert Figure 1 Here

In the short -run, to maintain money market equilibrium, the increased quantity of money would have to be matched by the money market schedule shifting out to Q'Q'. Due to the assumption that exchange rates and asset markets adjust fast relative to goods market, the nominal money supply raises but the price level is temporarily fixed. Therefore, the short-run equilibrium is at point $B$.

But in the long run, the price level could go up in order to maintain money market equilibrium. According to equation (2), the demand for real balances will go down. Therefore, the domestic interest rate $r$ could fall less then the short-run. Thus the new long-run equilibrium is at point $\mathrm{C}$, where both goods and money markets clear and exchange rate and price changes exactly reflect the increasing in money. As a result, the short-run initial depreciation of the exchange rate on impact must be larger than the long-run depreciation, i.e. the new short-run exchange rate e is larger than the new long-run exchange rate e'. That is, a monetary expansion results in an overshooting exchange rate.

\section{The Strength of the Dornbusch Overshooting Hypothesis}

Firstly, even with the inevitable onslaught of more modern approaches, the Dornbusch overshooting hypothesis remains a central tool for policy analysis. It is not only a framework for considering international monetary policy but also a model for understanding exchange rates. The hypothesis shows that with sticky prices in goods market, exchange rate volatility is needed to temporarily equilibrate the economy in response to monetary policies. The general approach has been applied to different problems, including the "Dutch disease", the choice of exchange rate regime, commodity price volatility and analysis of disinflation in developing countries (Rogoff, 2002). Sichei et al. (2005) suggest that the Dornbusch overshooting model appears to underlie the movement of the nominal Rand-USD exchange rate in the period 1994 to 2004 in South Africa (Figure 2).

Insert Figure 2 Here

Source: Sichei et al. (2005)

This model fits the data well and prices in South Africa are sticky which is derived from the high-income elasticity of demand. Thus increasing interest rates with a view to strengthening the Rand does the opposite in the short-run, i.e. depreciate the Rand in the first 8 quarters.

Secondly, the "Expectations and Exchange Rate Dynamics" was the first paper in international economics to marry sticky prices with rational expectations, both central features of today's mainstream. Rational expectations here imply that private agents must form exchange rate expectations in a way that is consistent with the model itself (Rogoff, 2002). In other words, the paper combined the Keynesian short-run analysis and the Monetarism long-run analysis in order to be more suitable to reality.

Thirdly, the Dornbusch overshooting hypothesis is used as a fundamental model to analyze open economy in international macroeconomics until now, precisely because it is theoretical simplicity, clarity and elegance. Rogoff (2002) pointed out that if one is in a pinch and needs a quick response to a question about how monetary policy might affect the exchange rate, most of people will still want to check any answer against Dornbusch's model.

\section{The Weakness of the Dornbusch Overshooting Hypothesis}

Although the Dornbusch overshooting hypothesis has keeping itself in the forefront of practical policy analysis for thirty years, it has been under severe attack since the model was published. Various version of critical evaluation of the 
overshooting phenomenon argue that undershooting may happen under some given circumstances. In general, the hypothesis can be problematic for those following critical evaluations.

\subsection{The Interest Elasticity of the Demand of Money}

In the extreme case, however, when $\alpha$, the interest elasticity of the demand for money, is infinity, as in the Dornbusch hypothesis, a different conclusion exists (Figure 3).

Insert Figure 3 Here

To analyze the effects of a monetary expansion, consider an initial long-run equilibrium at point A where money market curve QQ is vertical. A rise in the money supply causes this schedule shift out to Q'Q' which is also vertical. The exchange rate reaches immediately its long-run value, i.e. the short-run equilibrium at pint $B$ is on the same line with the long-run equilibrium at point $\mathrm{C}$. Therefore, the adjustment in short-run coincides with the adjustment in long-run, i.e. the new short-run exchange rate e equals the new long-run exchange rate e'. Neither overshooting nor undershooting happens under this circumstance.

\subsection{The Imperfect Capital Mobility}

Dornbusch assumed that money markets clear instantaneously while adjustment in goods markets is sluggish. The hypothesis emphasizes that the key factor determining whether the exchange rate overshoots or undershoots its equilibrium value is the speeds of adjustment in goods and money markets. The hypothesis assumes the perfect capital mobility and the complete flexibility of exchange rate. However, in real markets imperfect or low capital mobility happens frequently. At this moment the QQ schedule is positively sloped and the current account of balance of payment dynamics can have large medium term impacts on real exchange rates (Figure 4).

\section{Insert Figure 4 Here}

A trade deficit of the current account will require a depreciation of domestic currencies. One often sees this pattern in practice, particularly for countries that are forced to quickly reverse current account balances (Rogoff, 2002). It offers a typical instance that the correlation of real exchange rate and current account imbalances in Thailand, Korea and Indonesia in the 1990s (see Figures 5 to 7). Since the capital mobility is imperfect, a monetary expansion causes the QQ schedule shift out to Q'Q'. It is shown in Figure 4 that the new short-run exchange rate e is smaller than the new long-run exchange rate e'. In other words, a monetary expansion results in exchange rate undershooting.

Insert Figure 5 Here

Insert Figure 6 Here

Insert Figure 7 Here

Frenkel and Rodriguez (1982) modified the Dornbusch's model and allowed a finite speed of adjustment in money markets. It shown that under this circumstance, the short-run effects of a monetary expansion depend on the degree of capital mobility. When capital is highly mobile, the exchange rate must overshoot its long-run value, but when capital is relatively immobile, the exchange rate undershoots its long-run value.

\subsection{The Long-run Expenditure Function}

The Dornbusch overshooting hypothesis implies that the expenditure function is given. But in practice it will be illustrated that the effects of a monetary expansion on the dynamics of exchange rates and in particular on whether exchange rates overshooting or undershooting their equilibrium path depend critically on the variance of expenditure function.

For instance, the expenditure function of a small net importer of tradable goods country will be assumed as equation (4) below.

$$
\mathrm{P}=\alpha \mathrm{Pt}+(1-\alpha) \mathrm{Pnt}
$$

Where P, Pt and Pnt denote the price level, prices of tradable goods and prices of non-tradable goods; $\alpha$ is the percentage coefficient of trade portfolio. Let $\alpha$ equal 3, i.e. $(1-\alpha)$ will be 7. In the short-run, the equation (4) is fixed. Thus a $10 \%$ monetary expansion causes a $3 \%$ increase in prices of tradable goods and a $7 \%$ increase in prices of non-tradable goods respectively. Moreover, the domestic currency depreciates. But during the long-run, the expenditure function can be changed according to new information. Since the prices of non-tradable goods have increased more than tradable goods, the country will shift its expenditure to the tradable goods. Therefore, $\alpha$ will be changed into 5 , i.e. $(1-$ $\alpha$ ) will also equal to 5 . Under this circumstance, the exchange rates move only imposed by the prices of tradable goods. As a result, the adjustment of exchange rate in short-run less than the adjustment in long-run, i.e. the exchange rate must be undershooting.

\subsection{The Empirical Data}

In the first place, Rogoff (2002) points out that the basic problem with the Dornbusch overshooting hypothesis is that whereas it seems to capture major turning points in monetary policy quite well, the model does not capture all the other 
huge exchange rate swings that regularly take place. Thus formally testing the Dornbusch model is easier said than done. To take the model to the data, one needs to resolve many issues. This drawback can be described with the help of a graph of the USD rate versus the German Mark (Figure 8).

Insert Figure 8 Here

The solid line gives real exchange rate and the dashed line is the one-year real interest differential. A rise in the real exchange rate represents a depreciation of the Mark. A rise in the real interest differential represents a rise in German real interest rates relative to those prevailing in the United States. As one can see, the model does seem to say something about major turning points, though we will not press to see if it robustly passes regression tests (Rogoff, 2002).

In the second place, another piece of evidence comes from the co-movements of forward and spot exchange rates. Dornbusch's thought experiments of a one-time unanticipated change in the level of the money supply, the spot rate should move by more than the forward rate at any horizon. This excess movement is precisely the overshooting. However, the hypothesis has come under pressure from real data (Table 1).

Insert Table 1 Here

Indeed, as Table 1 illustrates, forward rate volatility is slightly lower than spot rate volatility over the sample period. The data are inconsistent with the Dornbusch overshooting hypothesis. As Flood (1981) highlighted that, in most cases; the overshooting model predicts that forward rates and spot rates will not move one for one in general. The exact co-movements may depend on the nature of the shock (real versus nominal, temporary versus permanent) and on the horizon of the forward rate.

\section{Conclusions}

This paper has analyzed and examined the Dornbusch overshooting hypothesis in models and empirical data. From what have been discussed above, we may safely draw those following conclusions.

First of all, the overshooting concept is an extraordinary framework for reflecting the relationship between international macroeconomics policy and exchange rate. It remained a central workhorse model in its original from for policy analysis over the past quarter century. In addition, the "Expectations and Exchange Rate Dynamics" was the first paper in international finance to marry sticky prices with rational expectations, both central features of today's mainstream. Moreover, the Dornbusch model defines a high-water mark of theoretical simplicity and elegance in international economics.

Secondly, it has been seen that exchange rate overshooting is not an intrinsic characteristic of the foreign exchange rate market and that it depends on a set of specific assumptions. As long as the interest elasticity of demand for money is infinity, the adjustment of exchange rate in short-run is equal to the long-run adjustment. In addition, when capital mobility is imperfect, i.e. the speed of adjustment in money markets is relatively immobile; the exchange rate undershoots its long-run value. Moreover, when the expenditure function can be changed during the long-run and where a country is a small net importer of tradable goods, the exchange rate must undershoot.

The last but not the least, the Dornbusch overshooting hypothesis about why exchange rates overshoot has proven of relatively limited value empirically, although a plausible case can be made that it captures the effects of major turning points in monetary policy.

\section{References}

Dornbusch. (1976). Expectations and Exchange Rate Dynamics. Journal of Political Economy, Vol. 84 (December 1976), Page 1161-1176.

Flood. (1980). Explanations of Exchange-Rate Volatility and Other Empirical Regularities in Some Popular Models of the Foreign Exchange Market. Carnegie-Rochester Conference Series on Public Policy, Vol. 15, Page 219-249.

Krugman. (2006). International Economics: Theory and Policy. Boston: Pearson Education.

Mussa. (1980). The Role of the Current Account in Exchange Rate Dynamics. Chicago: University of Chicago.

Mussa. (1982). A model of Exchange Rate Dynamics. Journal of Political Economy, Vol. 90 (February 1982), Page 74-104.

Rogoff. (2002). Dornbusch's Overshooting Model after Twenty-Five Years. Imf.org, Available URL:http://www.imf.org/external/np/speeches/2001/112901.htm.

Sichei, Gebreselasie and Akanbi. (2005). An Econometric Model of the Rand-US Dollar Nominal Exchange Rate. Web.up.ac.za. Available

URL:http://www.up.ac.za/dspace/bitstream/2263/4509/1/Sichei_Econometric\%282005\%29.pdf. 
Table 1. Variance of the Forward Rate Divided by Variance of Spot Rate

\begin{tabular}{|c|c|c|}
\hline COUNTRY & THREE MONTHS & ONE YEAR \\
\hline Canada & 0.88 & 0.89 \\
\hline France & 1.08 & 1.07 \\
\hline Germany & 0.88 & 0.87 \\
\hline Italy & 0.92 & 0.91 \\
\hline Japan & 0.99 & 0.99 \\
\hline United Kingdom & 1.00 & 1.00 \\
\hline
\end{tabular}

Source: IMF, International Financial Statistics; IMF staff estimates.

Note: Quarterly data for 1979 Q-I 2000 Q-IV.

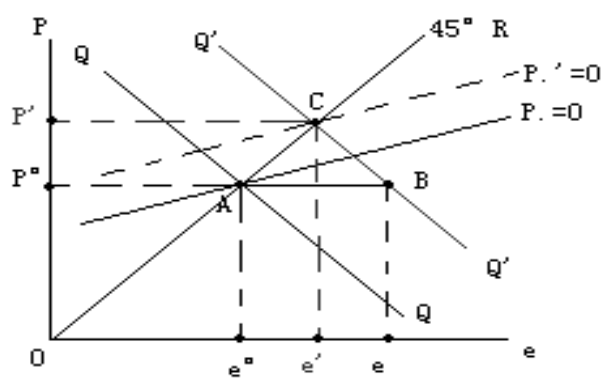

Figure 1. The Dornbusch Overshooting Hypothesis Display

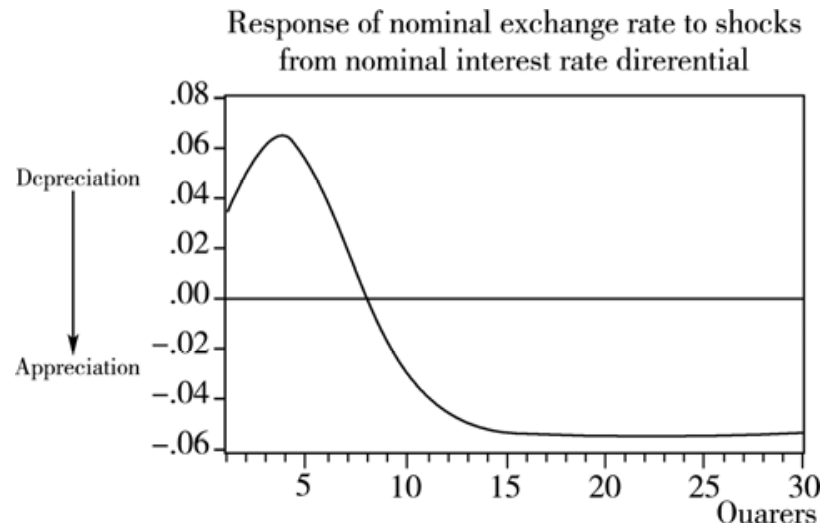

Figure 2. Response of Nominal exchange rate to Stocks

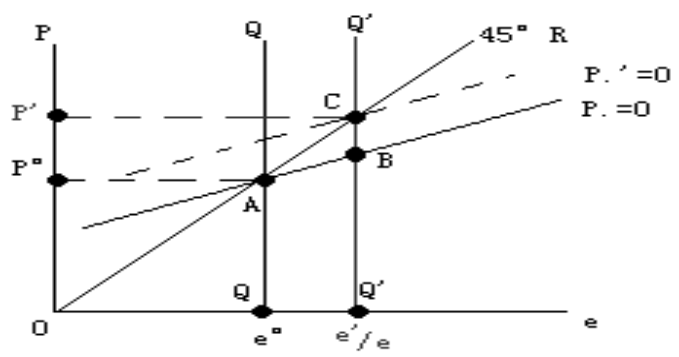

Figure 3. The Interest Elasticity of the Demand of Money 


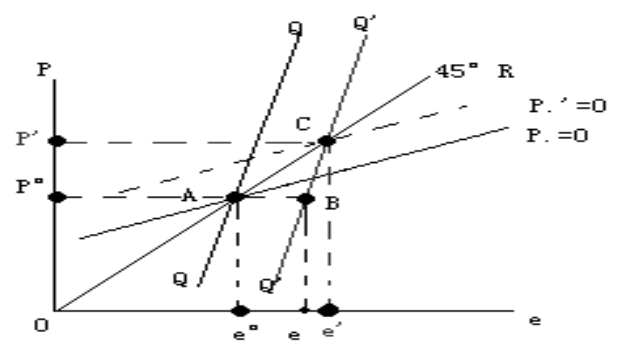

Figure 4. The Imperfect Capital Mobility
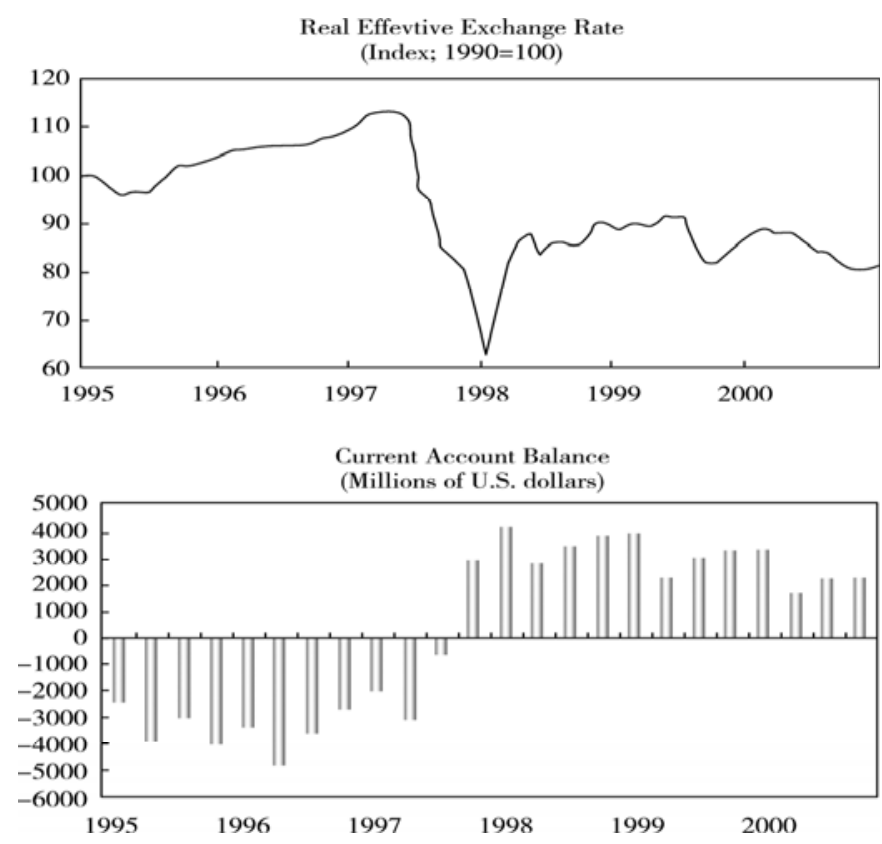

Figure 5. Real Exchange Rate and Current Account Imbalance in Thailand
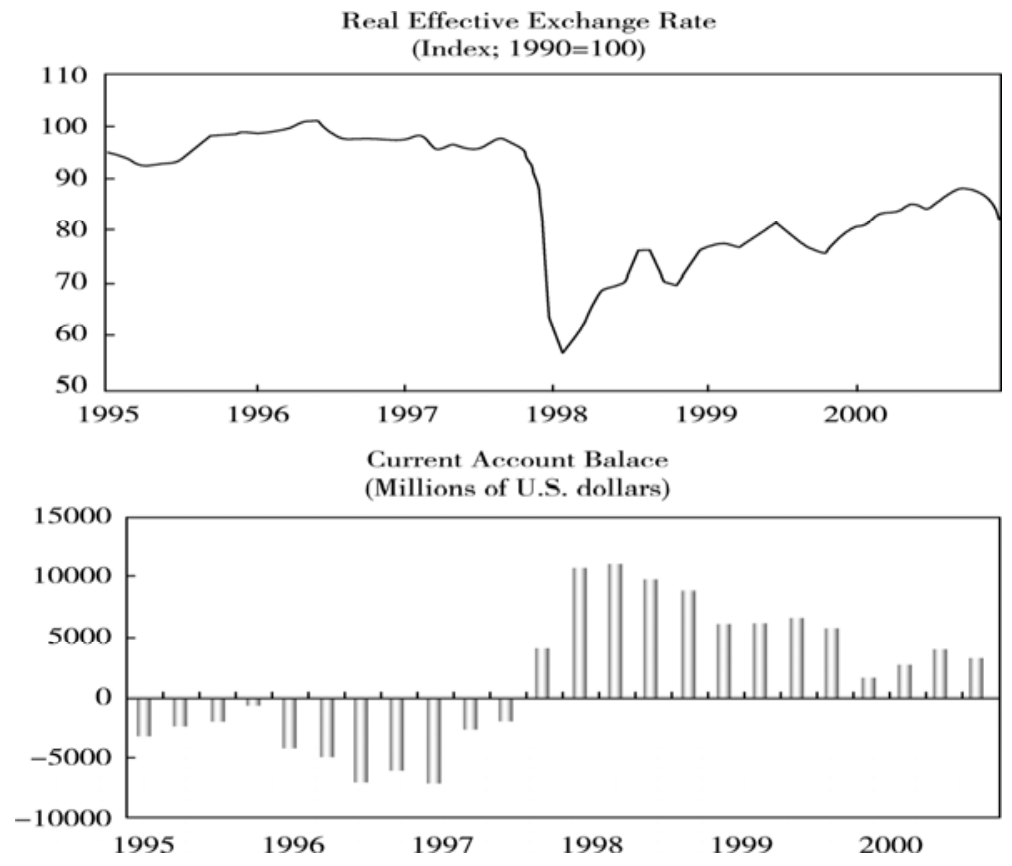

Figure 6. Real Exchange Rate and Current Account Imbalance in Korea 


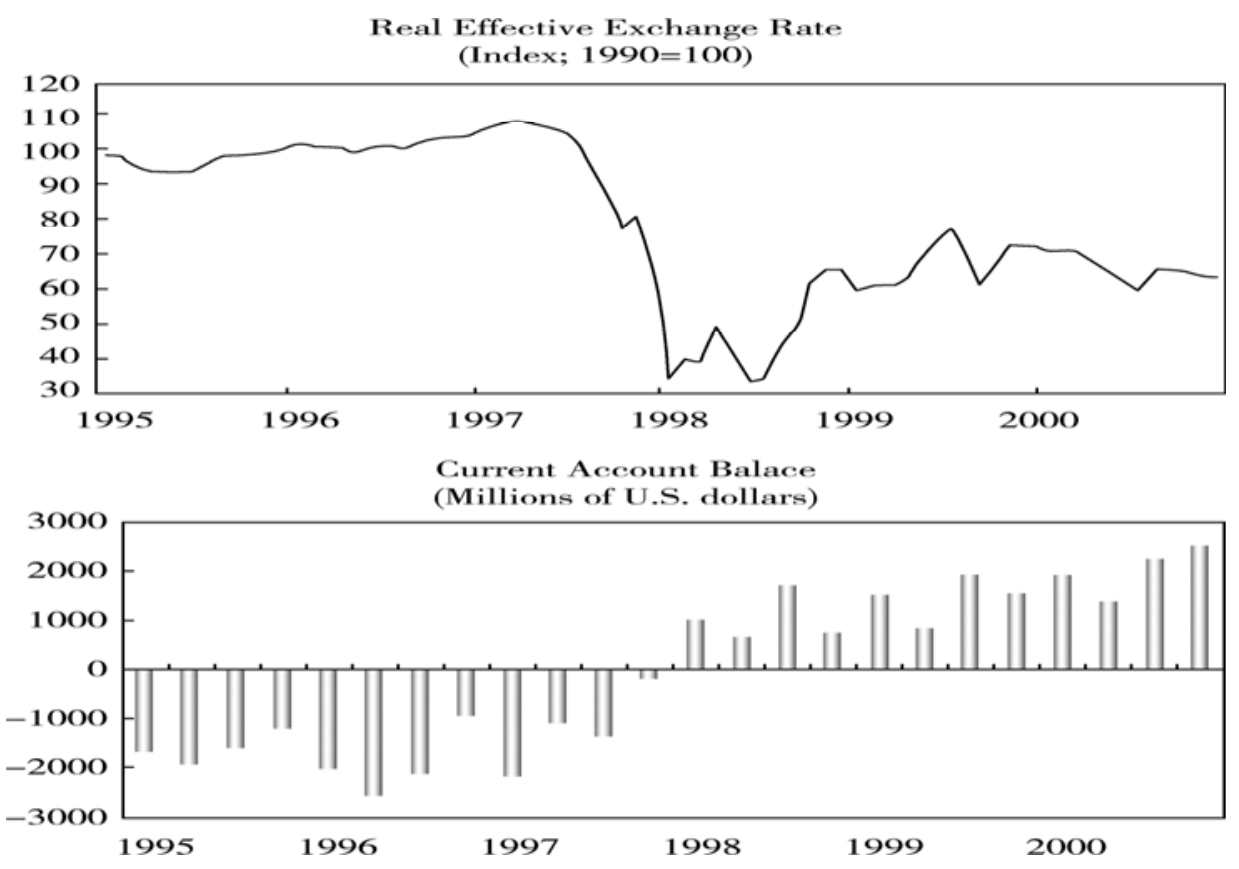

Figure 7. Real Exchange Rate and Current Account Imbalance in Thailand

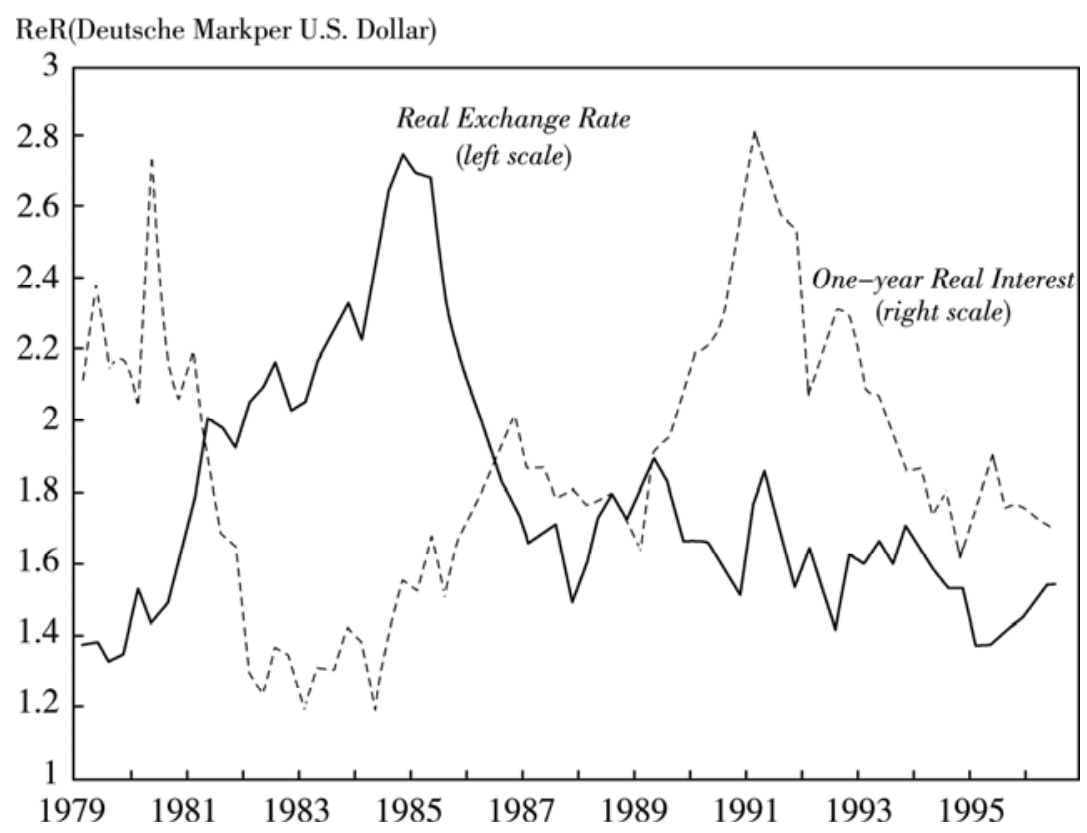

Figure 8. USD rate Versus German Mark 